\title{
S100 calgranulin proteins S100A8, S100A9 and S100A12 are expressed in the inflamed gastric mucosa of Helicobacter pylori-infected children
}

\author{
Steven T Leach PhD ${ }^{1}$, Hazel M Mitchell PhD², Carolyn L Geczy PhD ${ }^{3}$, \\ Philip M Sherman $\mathrm{MD}^{4}$, Andrew S Day MD ${ }^{1,5}$
}

\begin{abstract}
ST Leach, HM Mitchell, CL Geczy, PM Sherman, AS Day. S100 calgranulin proteins S100A8, S100A9 and S100A12 are expressed in the inflamed gastric mucosa of Helicobacter pyloriinfected children. Can J Gastroenterol 2008;22(5):461-464.

The expression of the inflammatory S100 calgranulin proteins (S100A8, S100A9 and S100A12) in normal and Helicobacter pyloriinfected gastric mucosa of children were examined. S100A8, S100A9 and S100A12, which were virtually absent in normal gastric mucosa, were highly expressed in $\mathrm{H}$ pylori-infected mucosa. This expression correlated with the severity of gastritis $(r=0.9422, \mathrm{P}<0.05)$. S100 calgranulins may be involved in bacterial-induced gastritis and may limit bacterial growth.
\end{abstract}

Key Words: Calprotectin; Gastric mucosa; Gastritis; Helicobacter pylori; S100A12

\section{Les calgranulines S100A8, S100A9 et S100A12 sont exprimées dans la muqueuse gastrique enflammée d'enfants infectés par Helicobacter pylori}

\begin{abstract}
L'expression des protéines calgranulines S100 inflammatoires (S100A8, S100A9 et S100A12) a été examinée dans la muqueuse gastrique d'enfants en santé et d'enfants infectés par Helicobacter pylori. Les calgranulines S100A8, S100A9 et S100A12, qui sont pour ainsi dire absentes dans la muqueuse gastrique normale, étaient fortement exprimées dans la muqueuse infectée par $H$. pylori. Cette expression était en corrélation avec la gravité de la gastrite $(r=0,9422, p<0,05)$. Les calgranulines $S 100$ pourraient être associées à la gastrite d'origine bactérienne et elles pourraient limiter la croissance bactérienne.
\end{abstract}

$\Gamma \mathrm{s}$ S100 calgranulin proteins (S100A8, S100A9 and S100A12) comprise approximately $45 \%$ of neutrophil cytoplasm. S100A8 and S100A12 are upregulated by bacterial lipopolysaccharides $(1,2)$. In general, the calgranulin proteins are associated with infection (3) and inflammation, including intestinal inflammation (4). One specific extracellular function of S100A8 and S100A9 is the regulation of leukocyte transmigration. Also, the calprotectin complex (a heterodimer of S100A8 and S100A9) has antimicrobial properties by virtue of its ability to sequester zinc (5). S100A12 is a potent monocyte chemoattractant (2) and activates mast cells (6). Expression of these S100 proteins in the upper gastrointestinal tract has not been defined.

Colonization of the stomach with Helicobacter pylori, a spiral-shaped bacterium, leads to a life-long gastric infection unless specifically eradicated. Infection results in gastritis with a small percentage of those infected developing peptic ulceration and gastric cancer (7). We aimed to establish whether S100A8, S100A9 and S100A12 are present in the normal gastric mucosa and whether $H$ pylori infection is associated with altered expression of these $\mathrm{S} 100$ proteins in the gastric mucosa.

\section{METHODS}

Patient demographics and $H$ pylori status

Eighteen children between eight and 18 years of age scheduled to undergo esophagogastroduodenoscopy at the Hospital for Sick Children (Toronto, Ontario) for investigation of upper gastrointestinal symptoms were consecutively enrolled in the present study before endoscopy. The inclusion criterion was upper gastrointestinal symptoms without a previous specific etiological diagnosis. Exclusion criteria included administration of antibiotics in the month preceding endoscopy, the use of proton pump inhibitors or histamine- 2 antagonists in the two weeks before endoscopy or a known history of $\mathrm{H}$ pylori infection. At endoscopy, antral biopsies were collected for microbiological culture and histological examination. The study was conducted in accordance with institutional guidelines, and was approved by the hospital's Research Ethics Review Board.

\section{Gastritis grading}

Sections $(5 \mu \mathrm{m})$ cut from formalin-fixed, paraffin-embedded antral biopsies were stained with hematoxylin-eosin (Amber

\footnotetext{
${ }^{1}$ School of Women's and Children's Health; ${ }^{2}$ School of Biotechnology and Biomolecular Sciences; ${ }^{3}$ Inflammatory Diseases Research Unit, School of Medical Sciences, University of New South Wales, Sydney, Australia; ${ }^{4}$ Hospital for Sick Children, University of Toronto, Toronto, Ontario;

${ }^{5}$ Department of Gastroenterology, Sydney Children's Hospital Randwick, Sydney, Australia

Correspondence: Dr Steven T Leach, Westfield Research Laboratories, Level 2, Sydney Children's Hospital Randwick, Sydney, New South Wales 2031, Australia. Telephone 6-129-382-1883, fax 6-129-382-1574, s.leach@unsw.edu.au

Received for publication December 6, 2007. Accepted February 24, 2008.
} 
Scientific Inc, Australia). Slides were blinded and one biopsy section from each patient was viewed with a light microscope (Nikon, Japan) at $\times 400$ magnification. The entire biopsy section was scanned and graded visually for neutrophil and/or mononuclear cell numbers: grade 0 (normal), grade 1 (mild), grade 2 (moderate) or grade 3 (marked), based on the grading system suggested by the updated Sydney system for classification and grading of gastritis (8). The numerical scores for each of the two variables (neutrophil grade and mononuclear grade) were combined to generate a single grade (with a maximum grade of 6) that was representative of the overall severity of gastritis.

\section{S100 immunofluorescence}

Serial sections $(5 \mu \mathrm{m})$ from formalin-fixed, paraffin-embedded antral biopsies were stained for S100A8, S100A9 and S100A12 by immunofluorescence. Sections were heated in $0.01 \mathrm{M}$ trisodium citrate in $0.0044 \mathrm{M}$ hydrochloride until boiling. The solution was removed from the heat source and sections were maintained in the heated solution for $15 \mathrm{~min}$. Sections were then blocked with $10 \%$ goat serum in $0.1 \%$ bovine serum albumin (BSA) (Sigma-Aldrich Co, USA) in phosphate-buffered saline (PBS) for $20 \mathrm{~min}$ at room temperature, then incubated overnight at $4^{\circ} \mathrm{C}$ with either polyclonal rabbit anti-S100A8 immunoglobulin G (IgG), anti-S100A9 IgG or anti-S100A12 IgG (prepared as previously described (2); cross-reactivity to the other calgranulins was absorbed out for each antiserum preparation) $(2 \mu \mathrm{g} / \mathrm{mL}$ in $0.05 \%$ saponin [Sigma-Aldrich Co] in PBS and BSA). Following extensive PBS washing, sections were incubated with Alexa Fluor 594 goat-antirabbit IgG (Molecular Probes Inc, USA) 1:200 in saponin/BSA/PBS for $2 \mathrm{~h}$ at room temperature, washed in PBS and then counterstained with $300 \mathrm{nM}$ (in PBS) 4'6-diamidino2-phenylindole-dihydrochloride (DAPI) (Molecular Probes Inc) for $5 \mathrm{~min}$ at room temperature before mounting in fluorescent mounting media (Dako, Denmark). Control slides were treated exactly as test slides, except that purified rabbit IgG was used as the primary antibody.

Serial biopsy sections, stained for S100A8, S100A9 or S100A12, were viewed at $\times 100$ magnification on an Axioplan 2 fluorescence microscope (Zeiss, Germany). Images were collected and analyzed using AxioVision software (Zeiss). The entire sections of one each of S100A8-, S100A9- and S100A12-stained biopsies were viewed for each patient and the two-dimensional biopsy area was calculated using the above software. All S100-positive cells were counted and the S100-positive cell density in the gastric mucosa was calculated.

\section{Statistical analysis}

The $\chi^{2}$ and Fisher's exact tests were used to assess sex distributions. Groups were compared by one-way ANOVA, with Tukey's multiple comparison test used for post-hoc analysis. Correlations were tested by Spearman's rho correlation. All statistics were generated using GraphPad Prism version 3.00 for Windows (GraphPad Software, USA) and are presented as mean \pm SD. Significance was accepted if $\mathrm{P}<0.05$.

\section{RESULTS}

The eighteen children were divided into three groups. Six children (four boys and two girls, mean age $14.9 \pm 1.2$ years) identified as $\mathrm{H}$ pylori-positive, as indicated by positive $\mathrm{H}$ pylori culture $(n=4)$, histology assessment $(n=6)$ or both $(n=4)$, were designated as group 1 (gastritis-positive and $\mathrm{H}$ pylori-positive). Six children (four boys and two girls, mean age $11.6 \pm 2.6$ years), designated as group 2, had no indications of gastritis and had negative $H$ pylori culture and histology. Finally, six children (two boys and four girls, mean age $10.1 \pm 1.3$ years), designated as group 3, presented with evidence of gastritis, but were negative for $\mathrm{H}$ pylori culture and histology. The children in group 1 were significantly older $(\mathrm{P}<0.05)$ than children in the other groups, although there was no significant difference in sex distribution among the groups. Gastritis scores for the groups were $4.8 \pm 2.1$ for group $1,0.3 \pm 0.5$ for group 2 and $2.2 \pm 2.2$ for group 3 .

\section{S100-positive cells in the gastric mucosa}

S100A8-, S100A9- and S100A12-specific staining with these antibodies has previously been reported $(2,4)$. Further, all control sections had no indications of nonspecific binding. The normal gastric mucosa of children in group 2 contained very few S100A8-positive (Figure 1A), S100A9-positive (Figure 1B) or S100A12-positive cells (Figure 1C). Similarly, the gastric mucosa of children in group 3 had low numbers of S100-positive cells. In contrast, S100A8-positive (Figure 1D), S100A9positive (Figure 1E) and S100A12-positive cells (Figure 1F) were prominent throughout the gastric mucosa of biopsies from children in group 1 . There was limited cellular expression of S100A9 (Figure 1G). Unlike S100A8 (Figure 1H) and S100A12 (Figure 1F), S100A9 was prominent in the underlying matrix and was not generally associated with cellular structures. S100A8, S100A9 and S100A12 were seen only within the lamina propria and not - in any group - in the gastric epithelium.

\section{S100-positive cell numbers}

There were significantly more S100A8-positive cells in the gastric mucosa of children in group $1\left(89 \pm 69\right.$ cells $\left./ \mathrm{mm}^{2}\right)$ $(\mathrm{P}<0.01)$ than in the gastric mucosa of children from group 2 $\left(0 \pm 0\right.$ cells $\left./ \mathrm{mm}^{2}\right)$ and group $3\left(4 \pm 9\right.$ cells $\left./ \mathrm{mm}^{2}\right)$. Furthermore, numbers of S100A8-positive cells positively correlated with gastritis scores $(\mathrm{r}=0.9411, \mathrm{P}<0.05)$.

Similar to S100A8-positive cell numbers, there were significantly more S100A12-positive cells in the gastric mucosa of children in group $1\left(100 \pm 113\right.$ cells $\left./ \mathrm{mm}^{2} ; \mathrm{P}<0.05\right)$ than in the gastric mucosa of group $2\left(0 \pm 0\right.$ cells $\left./ \mathrm{mm}^{2}\right)$ and group 3 $\left(0.3 \pm 0.8 \mathrm{cells} / \mathrm{mm}^{2}\right)$ children, although there was a weaker correlation between S100A12-positive cells and gastritis scores $(r=0.7590, P>0.05)$. S100A9-positive cell numbers could not be assessed because staining was predominantly concentrated in the extracellular matrix.

\section{DISCUSSION}

The present study strongly links the expression of the S100 calgranulins S100A8, S100A9 and S100A12 in the gastric mucosa to $H$ pylori infection. These proteins were not evident in normal noninflamed mucosa that was free of $H$ pylori infection, but were widespread throughout the inflamed gastric mucosa of $H$ pylori-infected children (group 1). Furthermore, there were very few calgranulin-positive cells in the mucosa of group 3 (gastritis-positive and $H$ pylori-negative) children, although the level of gastritis was not as severe as in the mucosa of children in group 1. Therefore, we are unable to conclude whether the presence of these calgranulin-positive cells is the direct result of $\mathrm{H}$ pylori infection or a result of inflammation. Nevertheless, in group 1 children, S100A8 and 


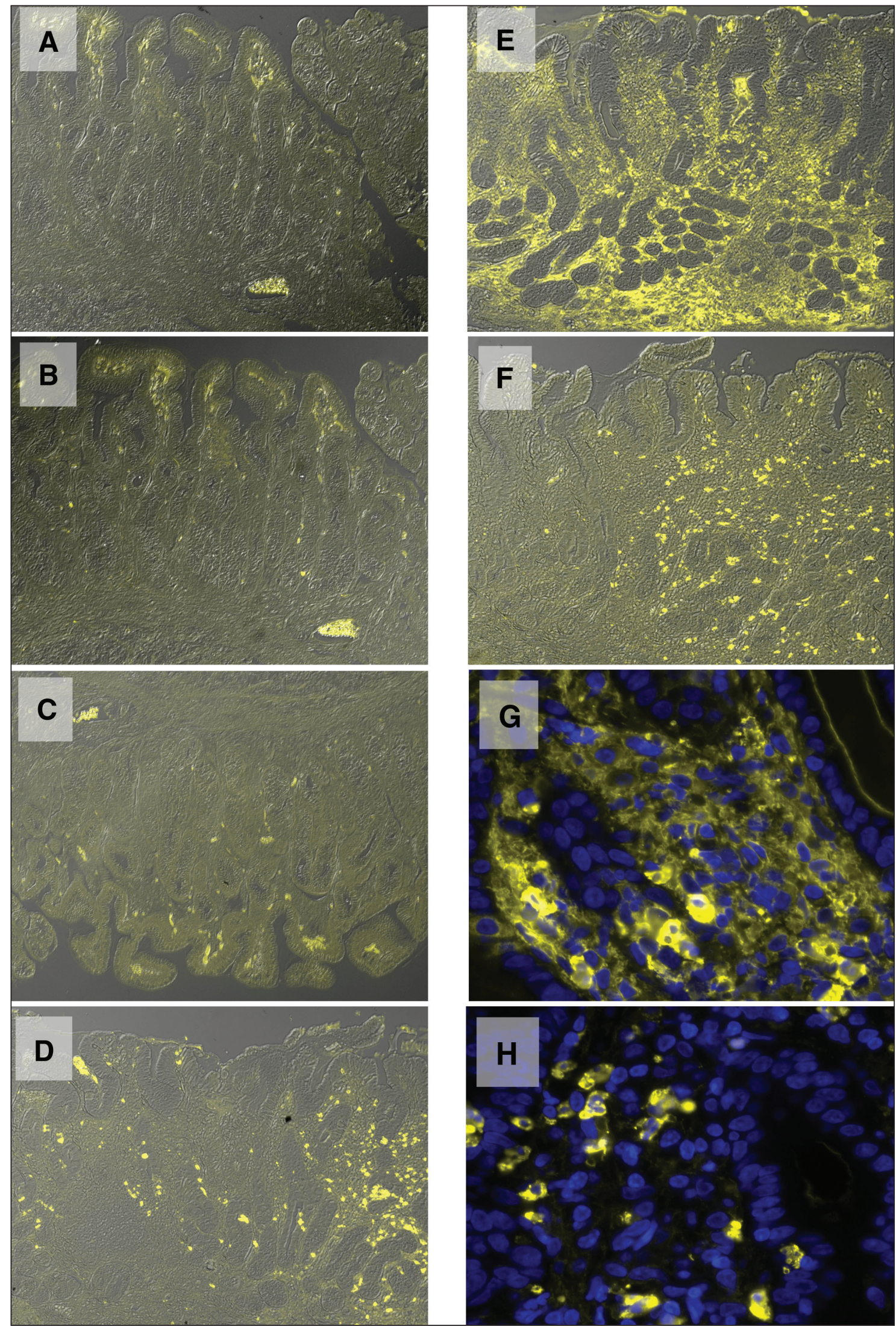

Figure 1) S100-positive cells in the gastric mucosa. Gastric biopsies were obtained from six gastritis-negative and $\mathrm{H}$ pylorinegative children (group 2 representative sections are shown $[\mathbf{A}, \mathbf{B}, \mathbf{C}]$ ), and six gastritis-positive and $\mathrm{H}$ pylori-positive children (group 1 representative sections are shown $[\mathrm{D}, \mathrm{E}, \mathrm{F}])$. Sections were processed and stained with anti-S100A8 (A,D), antiS100A9 $(\mathrm{B}, \mathrm{E})$ or anti-S100A12 $(\mathrm{C}, \mathrm{F})$ antibodies. Higher magnification $(\times 630)$ views of the gastric mucosa are shown for S100A9-stained $(\mathrm{G})$ and S100A8-stained $(\mathrm{H})$ gastric mucosa; nuclei are stained blue 
S100A12 were strongly expressed within cells distributed throughout the lamina propria. S100A9 was also abundant in the infected mucosa, although it was mainly associated with the underlying tissue matrix (Figure 1G). S100A9 binds to heparan sulphate and matrix glycosaminoglycans with a high affinity (9). This would allow for its concentration in the lamina propria following release from cells. We speculate that S100A9 may have multiple functions in the gastric mucosa during $H$ pylori infection. Initially, extracellular S100A9 may generate a chemotactic gradient that allows for neutrophil recruitment (10). This may be particularly efficient when S100A9 is matrix-bound and may occur in a manner similar to chemokine ligand 27, a chemokine that binds to the extracellular matrix and promotes leukocyte adhesion and chemotaxis in skin inflammation (11). Furthermore, at high concentrations, it is possible that S100A9 may display bacteriostatic properties by chelating zinc (5), thereby limiting the availability of this essential nutrient to $H$ pylori.

In comparison, we speculate that S100A8 may have a protective role in the gastric mucosa. Murine S100A8 is induced by lipopolysaccharides in activated macrophages, and its expression is dependent on interleukin-10 and prostaglandin $\mathrm{E}_{2}$ via a cyclic AMP-mediated pathway (1). Human and murine S100A8 proteins are exquisitely sensitive to oxidation and are proposed to be oxidant scavengers (12). Indeed, S100A8-positive cell numbers appeared to be closely associated with gastritis, and numbers increased with gastritis severity. Therefore, S100A8 may have a role in protecting the gastric mucosa from oxidative damage and cytokine-induced injury during $H$ pylori infection.

In contrast, we speculate that S100A12 expression during $\mathrm{H}$ pylori infection may promote gastritis, because it is known that S100A12 is a potent monocyte chemoattractant (2), as well as a potent activator of mast cells (6). Given that mast cell numbers have been shown to be increased in the gastric mucosa during $\mathrm{H}$ pylori infection and that mast cell degranulation and mediator release is proposed to play an important role in $\mathrm{H}$ pylori-mediated gastritis (13), we suggest that S100A12 upregulation in the gastric mucosa during $\mathrm{H}$ pylori infection may contribute to the development of this gastritis.

The precise identification of the infiltrating calgranulinpositive cells was not determined in the present study. The cell types that express the calgranulin proteins include neutrophils (14), macrophages (15), epithelial cells (16), eosinophils (17) and keratinocytes (18). Furthermore, gastritis grading indicates an influx of inflammatory cells (neutrophils and macrophages) in the gastric mucosa. Therefore, it is likely that neutrophils and macrophages are the predominant source of calgranulin proteins in the inflamed gastric mucosa, but further studies are needed to confirm this.

\section{CONCLUSIONS}

S100A8, S100A9 and S100A12 proteins, which were not present in the normal gastric mucosa, were abundantly expressed in the gastric mucosa of $H$ pylori-infected children (group 1). These findings are the first to show the expression of the S100 calgranulin proteins in $H$ pylori-infected gastric mucosa and to indicate that they may be involved in the host response at this site. Based on these preliminary findings, further investigation into the role of S100 proteins in $\mathrm{H}$ pylorirelated disease is warranted.

ACKNOWLEDGEMENTS: The present study was supported by a Sylvia and Charles Viertel Charitable Foundation Clinical Investigator Grant, awarded to Andrew S Day.

\section{REFERENCES}

1. Xu K, Yen T, Geczy CL. Il-10 up-regulates macrophage expression of the S100 protein S100A8. J Immunol 2001;166:6358-66.

2. Yang Z, Tao T, Raftery MJ, Youssef P, Di Girolamo N, Geczy CL. Proinflammatory properties of the human S100 protein S100A12. J Leukoc Biol 2001;69:986-94.

3. Herndon BL, Abbasi S, Bennett D, Bamberger D. Calcium-binding proteins MRP 8 and 14 in a Staphylococcus aureus infection model: Role of therapy, inflammation, and infection persistence. J Lab Clin Med 2003;141:110-20.

4. Leach ST, Yang Z, Messina I, et al. Serum and mucosal S100 proteins, calprotectin (S100A8/S100A9) and S100A12, are elevated at diagnosis in children with inflammatory bowel disease. Scand J Gastroenterol 2007;42:1321-31.

5. Sohnle PG, Hunter MJ, Hahn B, Chazin WJ. Zinc-reversible antimicrobial activity of recombinant calprotectin (migration inhibitory factor-related proteins 8 and 14). J Infect Dis 2000;182:1272-5.

6. Yang Z, Yan WX, Cai H, et al. S100A12 provokes mast cell activation: A potential amplification pathway in asthma and innate immunity. J Allergy Clin Immunol 2007;119:106-14.

7. Blaser MJ, Chyou PH, Nomura A. Age at establishment of Helicobacter pylori infection and gastric carcinoma, gastric ulcer, and duodenal ulcer risk. Cancer Res 1995;55:562-5.

8. Dixon MF, Genta RM, Yardley JH, Correa P. Classification and grading of gastritis. The updated Sydney System. International Workshop on the Histopathology of Gastritis, Houston 1994. Am J Surg Pathol 1996;20:1161-81.

9. Robinson MJ, Tessier P, Poulsom R, Hogg N. The S100 family heterodimer, MRP-8/14, binds with high affinity to heparin and heparan sulfate glycosaminoglycans on endothelial cells. J Biol Chem 2002;277:3658-65.

10. Ryckman C, Vandal K, Rouleau P, Talbot M, Tessier PA. Proinflammatory activities of S100: Proteins S100A8, S100A9, and S100A8/A9 induce neutrophil chemotaxis and adhesion. J Immunol 2003;170:3233-42.

11. Homey B, Alenius H, Muller A, et al. CCL27-CCR10 interactions regulate T cell-mediated skin inflammation. Nat Med 2002;8:157-65.

12. Raftery MJ, Yang Z, Valenzuela SM, Geczy CL. Novel intraand inter-molecular sulfinamide bonds in S100A8 produced by hypochlorite oxidation. J Biol Chem 2001;276:33393-401.

13. Nakajima S, Bamba N, Hattori T. Histological aspects and role of mast cells in Helicobacter pylori-infected gastritis. Aliment Pharmacol Ther 2004;20(Suppl 1):165-70.

14. Bengis-Garber C, Gruener N. Calcium-binding myeloid protein $(\mathrm{P} 8,14)$ is phosphorylated in $\mathrm{PMet}-\mathrm{Leu}$-Phe-stimulated neutrophils. J Leukoc Biol 1993;54:114-8.

15. Rugtveit J, Scott H, Halstensen TS, Fausa O, Brandtzaeg P. Differential expression of leucocyte protein L1 (calprotectin) by monocytes and intestinal macrophages. Adv Exp Med Biol 1995;371A:207-10.

16. Lugering N, Stoll R, Kucharzik T, et al. Immunohistochemical distribution and serum levels of the $\mathrm{Ca}(2+)$-binding proteins MRP8, MRP14 and their heterodimeric form MRP8/14 in Crohn's disease. Digestion 1995;56:406-14.

17. Brandtzaeg P, Dale I, Fagerhol MK. Distribution of a formalinresistant myelomonocytic antigen (L1) in human tissues. I. Comparison with other leukocyte markers by paired immunofluorescence and immunoenzyme staining. Am J Clin Pathol 1987;87:681-99.

18. Eversole LR, Miyasaki KT, Christensen RE. The distribution of the antimicrobial protein, calprotectin, in normal oral keratinocytes. Arch Oral Biol 1992;37:963-8. 


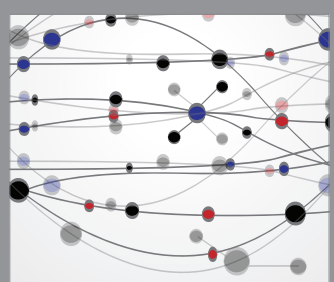

The Scientific World Journal
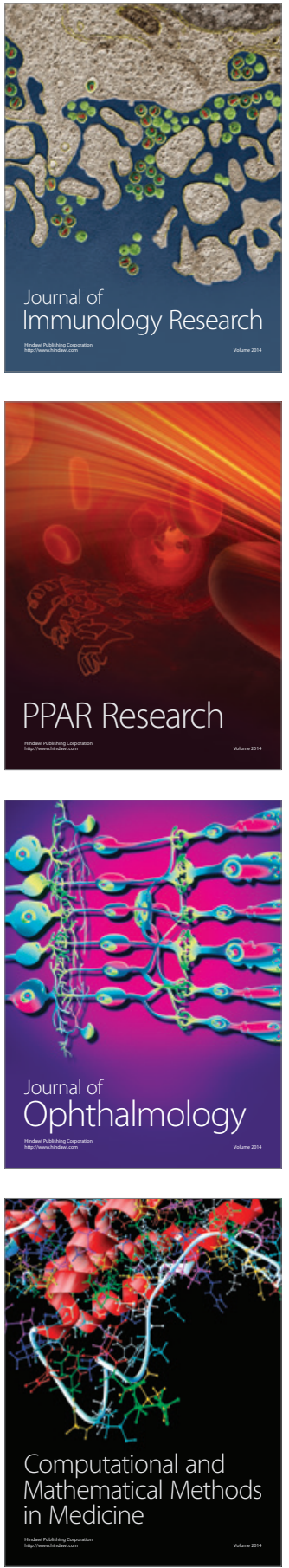

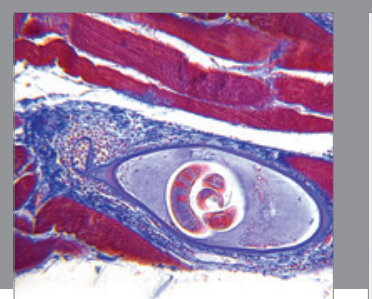

Gastroenterology Research and Practice

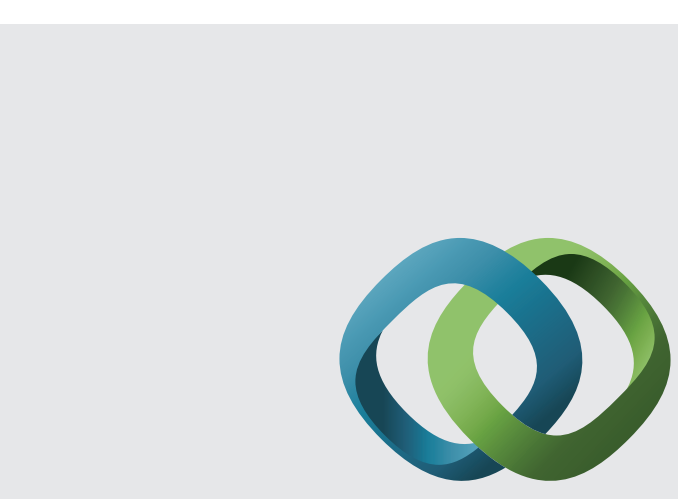

\section{Hindawi}

Submit your manuscripts at

http://www.hindawi.com
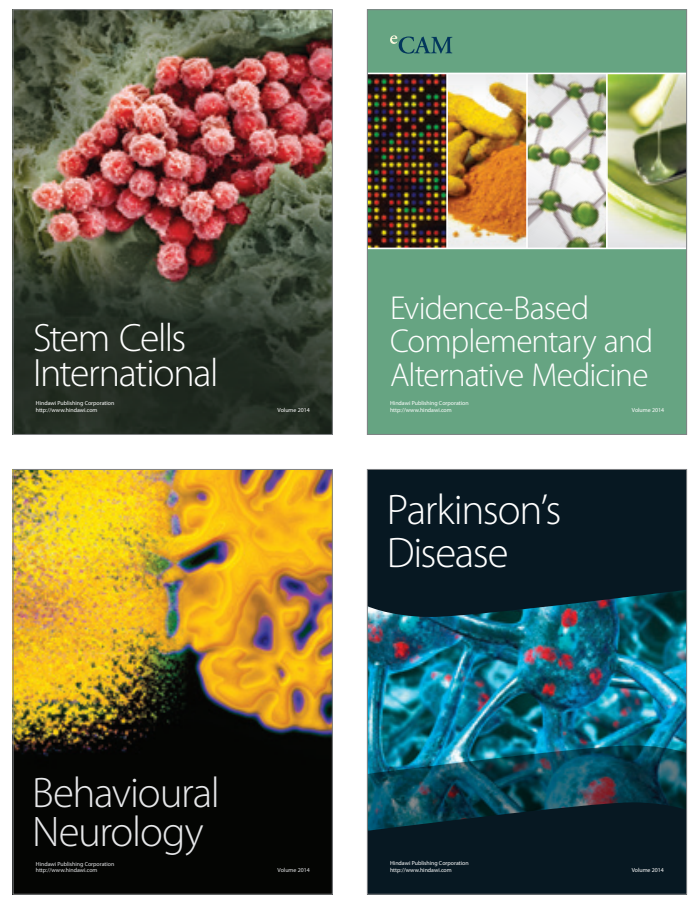
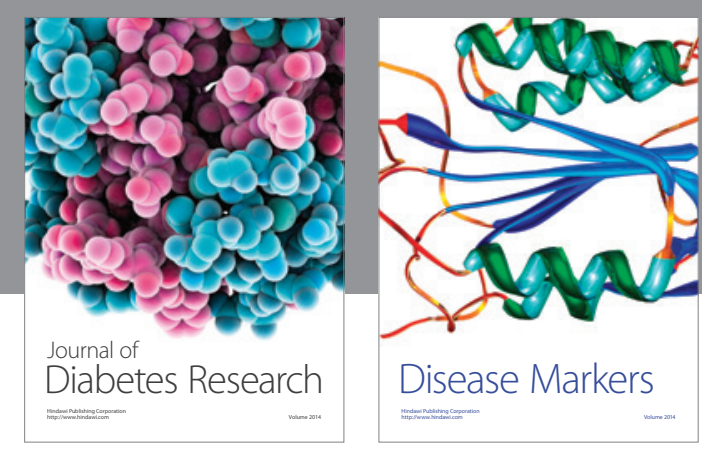

Disease Markers
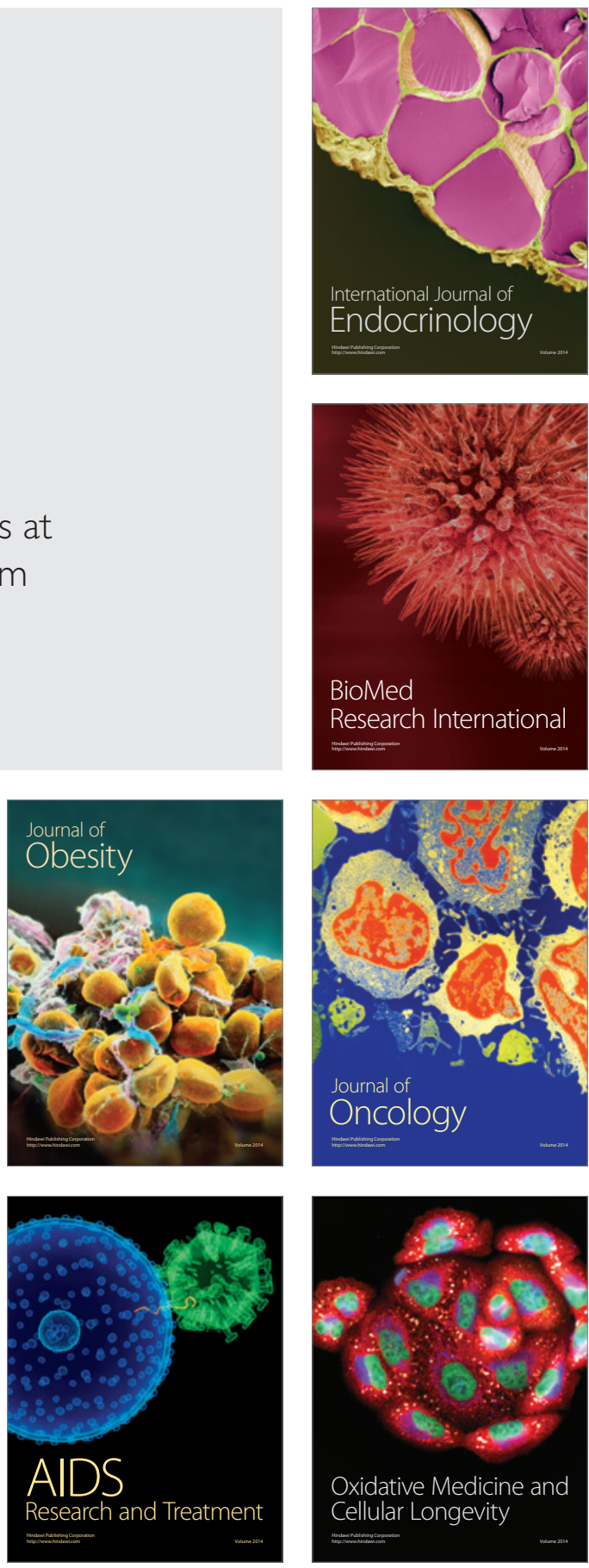